\title{
Estimating Elephant-Grass Adaptability and Stability for Energy-Biomass Production by Regression Models
}

\author{
Alexandre Gomes de Souza ${ }^{1}$, Yure Pequeno de Souza ${ }^{1}$, Rogério Figueiredo Daher ${ }^{1}$, Verônica Brito da Silva ${ }^{2}$, \\ Geraldo de Amaral Gravina ${ }^{1}$, Marcelo Vivas ${ }^{1}$, Wanessa Francesconi Stida ${ }^{1}$, Ana Kesia Faria Vidal ${ }^{1}$, \\ Bruna Rafaela da Silva Menezes ${ }^{3}$, Rafael Souza Freitas ${ }^{1}$, Maxwel Rodrigues Nascimento ${ }^{1}$, \\ Raiane Mariani Santos ${ }^{1}$, Josefa Grasiela Silva Santana ${ }^{1}$, Cleudiane Lopes Leite ${ }^{1}$, \\ José Tiago Barroso Chagas ${ }^{4} \&$ Antônio Vander Pereira ${ }^{5}$ \\ ${ }^{1}$ Universidade Estadual do Norte Fluminense Darcy Ribeiro, Campos dos Goytacazes, RJ, Brazil \\ ${ }^{2}$ Universidade Federal do Piauí, Teresina, PI, Brazil \\ ${ }^{3}$ Universidade Federal Rural do Rio de Janeiro, Seropédica, RJ, Brazil \\ ${ }^{4}$ Universidade Federal de Viçosa, Viçosa, MG, Brazil \\ ${ }^{5}$ Empresa Brasileira de Pesquisa Agropecuária, Juiz de Fora, MG, Brazil \\ Correspondence: Alexandre Gomes de Souza, Universidade Estadual do Norte Fluminense Darcy Ribeiro, Postal \\ Code: 28035-200, Campos dos Goytacazes, RJ, Brazil. E-mail: alexandre.souza.agronomo@gmail.com
}

Received: December 15, 2020

doi:10.5539/jas.v13n3p68
Accepted: January 18, $2021 \quad$ Online Published: February 15, 2021

URL: https://doi.org/10.5539/jas.v13n3p68

\begin{abstract}
In Brazil, elephant grass has been researched for energy generation, as it represents an alternative energy source by virtue of its biomass production. The present study was developed to examine the adaptability and energy-biomass production stability of 73 elephant-grass genotypes under a biannual-harvest regime, using the methodologies proposed by Eberhart and Russell and Cruz. The experiment was carried out at the northern region of Rio de Janeiro State, Brazil. Nine harvests and subsequent evaluations were performed at six-month intervals. Each harvest was considered an environment of genotype evaluation. After the plants were harvested, their dry matter yield (DMY) was estimated in $\mathrm{t} \mathrm{ha}^{-1}$ harvest. Combined analysis of variance revealed highly significant effects of genotypes, harvests, and genotype $\times$ harvest interaction, by the $\mathrm{F}$ test. In five of the nine evaluated harvests, the genotypes had an average dry matter yield greater than the overall mean. The method of Eberhart and Russel was effective in identifying highly adaptable elephant-grass genotypes with high dry matter production stability throughout the nine harvests. When the method of Cruz was used, no genotypes were found comprising high yielding ability, adaptability to unfavorable environments, responsiveness to environmental improvement, and high stability altogether.
\end{abstract}

Keywords: bisegmented regression, genotype $\times$ environment interaction, Pennisetum purpureum

\section{Introduction}

The world's energy mix is majorly constituted by finite sources-fossil fuels, mainly—which are responsible for the emission of a large amount of pollutant gases. These gasses aggravate the greenhouse effect, posing a threat to the earth's climate balance (Morais et al., 2009). Considering this reality and given the large demand for energy in the next years, there has been an increased awareness about a possible energy crisis in the future. Therefore, alternative energy sources, especially those which are renewable and environmentally sustainable, have been sought to reduce dependence on fossil fuels (Silva et al., 2018a; Freitas et al., 2018; Magalhões et al., 2017; Oliveira et al., 2017).

In this scenario, the exploitation of plant biomass emerges as an excellent alternative, because in addition to being a renewable energy source, this material carries economic and environmental advantages compared with the use of fossil fuels (Ibrahim et al., 2014). Within this context, elephant grass (Pennisetum purpureum Schum.), a plant of the family Poaceae, has caught the interest of researchers mainly because of its high efficiency in fixating atmospheric $\mathrm{CO} 2$ during the photosynthesis process. Further, the species has a high dry matter yield and a short cycle, coupled with biomass-quality characteristics such as elevated fiber contents. More specifically, it 
contains high levels of high-carbon components with high calorific value such as cellulose and lignin, as well as a high carbon/nitrogen (C/N) ratio (Paterlini et al., 2013; Mohammed et al., 2015).

In spite of all of these favorable characteristics, research focusing on the breeding of elephant grass for energy generation can be considered still incipient, especially when compared with that of many commodities. In this regard, the State University of Northern Rio de Janeiro (UENF) develops an elephant-grass breeding program aimed at the assessment of the viability of use of plant biomass and at the selection of high-yielding genotypes with appropriate biomass quality to be used in the generation of energy (Silva et al., 2017, 2018a, 2018b; Daher et al., 2014; Menezes et al., 2016; Sousa et al., 2016, 2017; Araújo et al., 2017).

In forage-plant breeding programs, in which plants are harvested several times during evaluations, a trait to be taken into account is the productive stability of genotypes. Breeders should select those that best adapt to different environmental conditions. In this way, materials with greater mean yield at different harvests and with smaller decreases in production during the periods of environmental stress should be identified and selected for the continuity of the breeding program (Sobrinho et al., 2005). Nevertheless, this selection may often be undermined by the presence of genotype $\times$ environment $(\mathrm{G} \times \mathrm{E})$ interactions, which result in genotypes showing different responses across distinct environments (Cunha et al., 2013).

Despite its importance, a simple analysis of the $G \times E$ interaction does not provide complete and precise information about the behavior of each genotype under various environmental conditions. Evaluations of phenotypic adaptability and stability should be undertaken to identify genotypes with a predictable behavior and which are responsive to environmental changes under specific or broad conditions (Cruz et al., 2014). There are several methods for the estimate of stability; e.g., regression analysis. Among these, the simple linear (Eberhart \& Russel, 1996) and two-segment (Cruz et al., 1989) regression methods stand out. In this case, the means and coefficients of regression and deviation in relation to the adjusted line are used as estimates of adaptability and stability of the studied genetic material (Cruz et al., 2012). However, there are no studies of regression applied to elephant grass for energy production in various environments.

On these bases, the present study proposes to evaluate the adaptability and energy-biomass production stability of 73 elephant-grass genotypes under a biannual-harvest regime, using the methodologies proposed by Eberhart and Russell (1996) and Cruz et al. (1989).

\section{Method}

The experiment was developed at the State Center for Research on Agro-energy and Waste Utilization (PESAGRO-RIO/CEPAAR), located in Campos dos Goytacazes, northern region of Rio de Janeiro State, Brazil $\left(21^{\circ} 44^{\prime} 47^{\prime \prime} \mathrm{S}\right.$ and $41^{\circ} 18^{\prime} 24^{\prime \prime} \mathrm{W}$, and an average altitude of $\left.11 \mathrm{~m}\right)$. The climate of the region is anAw type, according to the Köppen (1948) classification, and the soil is characterized as a dystrophic Argisol (EMBRAPA, 2006).

Seventy-three genotypes of elephant grass that compose the Active Germplasm Bank of the State University of Northern Rio de Janeiro (BAG-UENF) were evaluated (Table 1). Considering the expected genetic variability of these elephant grass genotypes, due to their cultivation on different continents, genetic divergences were characterized and estimated using RAPD and ISSR markers (Lima et al., 2011), as well as discrete morphological, quantitative and qualitative characteristics (Oliveira et al., 2014). The experiment was implemented in February 2011, using three-bud cuttings aligned with the base of a cutting touching the apex of another, which were planted into $10-\mathrm{cm}$-deep furrows. Upon planting, the area was fertilized with $100 \mathrm{~kg} \mathrm{ha}^{-1}$ $\mathrm{P}_{2} \mathrm{O}_{5}$ (single superphosphate). Ten months after planting, all genotypes were cut near the soil level (uniformity cut) and the area was top-dressed using $25 \mathrm{~kg} \mathrm{ha}^{-1}$ ammonium sulfate and $25 \mathrm{~kg} \mathrm{ha}^{-1}$ potassium chloride. 
Table 1. List of the 73 genotypes from the Active Germplasm Bank of elephant grass of UENF

\begin{tabular}{|c|c|c|c|c|c|}
\hline Id. & Genotype & Id. & Genotype & Id. & Genotype \\
\hline 1 & Elefante Colômbia & 26 & Mole de Volta Grande & 51 & Cameroon \\
\hline 2 & BAGCE 2 & 27 & Porto Rico & 52 & BAGCE 69 \\
\hline 3 & Três Rios & 28 & Napier & 53 & Guaçu \\
\hline 4 & Napier Volta Grande & 29 & Mercker Comum & 54 & Napierzinho \\
\hline 5 & Mercker Santa Rita & 30 & Teresopólis & 55 & IJ $7125 \mathrm{cv}$ EMPASC 308 \\
\hline 6 & Pusa Napier $N^{\circ} 2$ & 31 & Taiwan A-46 & 56 & IJ 7136 cv EMPASC 307 \\
\hline 7 & Gigante de Pinda & 32 & Duro de Volta Grande & 57 & IJ 7139 \\
\hline 8 & Napier Goiano & 33 & Mercker Comum Pinda & 58 & Goiano \\
\hline 9 & Mercker S. E. A & 34 & Turrialba & 59 & CAC 262 \\
\hline 10 & Taiwan A-148 & 35 & Taiwan A-146 & 60 & Ibitinema \\
\hline 11 & Porto Rico 534-B & 36 & Taiwan A-121 & 61 & Australiano \\
\hline 12 & Taiwan A-25 & 37 & Vrukwona & 62 & $13 \mathrm{AD}$ \\
\hline 13 & Albano & 38 & P 241 Piracicaba & 63 & $10 \mathrm{AD}$ IRI \\
\hline \multirow[t]{2}{*}{14} & Pusa Gigante Napier & 39 & BAGCE 51 & 64 & $07 \mathrm{AD}$ IRI \\
\hline & Elefante Híbrido 534-A & 40 & Elefante Cach.Itapemirim & 65 & Pasto Panamá \\
\hline 16 & Costa Rica & 41 & Capim Cana D'África & 66 & BAGCE 92 \\
\hline 17 & Cubano Pinda & 42 & Gramafante & 67 & 05 AD IRI \\
\hline 18 & Mercker Pinda & 43 & Roxo & 68 & $13 \mathrm{AD}$ IRI \\
\hline 19 & Mercker Pinda México & 44 & Guaçu/I.Z.2 & 69 & $03 \mathrm{AD}$ IRI \\
\hline 20 & Mercker 86 México & 45 & Cuba-115 & 70 & $02 \mathrm{AD}$ IRI \\
\hline 21 & Napier S.E.A. & 46 & Cuba-116 & 71 & $08 \mathrm{AD}$ IRI \\
\hline 22 & Taiwan A-143 & 47 & King Grass & 72 & BAG 86 \\
\hline 23 & Pusa Napier $N^{o} 1$ & 48 & Roxo Botucatu & 73 & BAG 87 \\
\hline 24 & Elefante de Pinda & 49 & Mineirão IPEACO & & \\
\hline 25 & Mineiro & 50 & Vruckwona Africano & & \\
\hline
\end{tabular}

The experiment was set up as a randomized block design with two replicates. Each experimental unit was represented by a genotype planted in $5.5-\mathrm{m}$ rows spaced $2 \mathrm{~m}$ apart, totaling $11 \mathrm{~m}^{2}$. The usable area was the $2-\mathrm{m}^{2}$ central part of the plot. Nine harvests, followed by evaluations, were performed at six-month intervals from June 2012 to December 2016. Each harvest was considered an assessment environment. After harvest, the plant's dry matter yield (DMY) was estimated in $\mathrm{t} / \mathrm{ha}$.harvest as the product of the fresh matter weight of whole plants $(\mathrm{kg})$ from each usable area $\left(2 \mathrm{~m}^{2}\right)$, obtained using a digital crane scale, and the dry matter percentage (\%DM), obtained by sampling those plants.

To estimate the \%DM, two tillers were collected at random, cut into pieces of 2 to $3 \mathrm{~cm}$, placed in a paper bag, weighed and taken to a forced ventilation oven at $65^{\circ} \mathrm{C}$ for 72 hours. Then the samples were weighed again to obtain the air-dried sample (ADS), according to the methodology described by Silva and Queiroz (2002). Subsequently, the dry samples were ground in a Willey mill with a $1 \mathrm{~mm}$ sieve and packed in plastic bags for the determination of the kiln dried sample (KDS). The ASE was then obtained using $2 \mathrm{~g}$ of each ground sample, which were kept in an oven at $105{ }^{\circ} \mathrm{C}$ for 12 hours and then weighed. Thus, $\% \mathrm{DM}$ was estimated from the multiplication of ADS and KDS.

After the homogeneity of residual variances was tested by Hartley's test, a combined analysis of variance of the data was undertaken. The joint ANOVA was performed using the following statistical model, as proposed by Ramalho et al. (2005):

$$
\mathrm{Y}_{\mathrm{IJK}}=\mathrm{m}+\mathrm{G}_{\mathrm{i}}+\mathrm{B}_{\mathrm{j}}+\varepsilon_{\mathrm{a}}+\mathrm{C}_{\mathrm{k}}+\varepsilon_{\mathrm{b}}+\mathrm{GC}_{\mathrm{ik}}+\varepsilon_{\mathrm{c}}
$$

where, $\mathrm{Y}_{\text {IJK }}$ : observed value pertaining to genotype i in block $\mathrm{j}$, at harvest $\mathrm{k}$; m: overall constant of the trial; $\mathrm{G}_{\mathrm{i}}$ : effect of genotype i; $\mathrm{B}_{\mathrm{j}}$ : effect of block $\mathrm{j}$; $\varepsilon_{\mathrm{a}}$ : 'a' error associated with genotype $\mathrm{i}$ in block $\mathrm{j}$; $\mathrm{C}_{\mathrm{k}}$ : effect of harvest $\mathrm{k}$; $\varepsilon_{\mathrm{b}}$ : 'b' error associated with block $\mathrm{j}$ at harvest $\mathrm{k} ; \mathrm{GC}_{\mathrm{ik}}$ : effect of the interaction between genotype $\mathrm{i}$ and harvest $\mathrm{k}$; and $\varepsilon_{\mathrm{c}}$ : 'c' error associated with genotype $\mathrm{i}$ in block $\mathrm{j}$, at harvest $\mathrm{k}$. 
The methods of Eberhart and Russell (1996) and Cruz et al. (1989) were used to evaluate the adaptability and stability of genotypes. The method of Eberhart and Russell (1996) is based on the following linear regression model:

$$
Y_{i j}=\widehat{\beta}_{0 i}+\widehat{\beta}_{1 i} I_{j}+\delta_{i j}+\varepsilon_{i j}
$$

where, $Y_{i j}$ : mean of genotype $i$ in environment $j$; $\widehat{\beta}_{0 \mathrm{i}}$ : overall mean of genotype $i ; \widehat{\beta}_{1 i}$ : linear regression coefficient that measures the response of genotype $i$ to the environmental variation; $\mathrm{I}_{\mathrm{j}}$ : coded environmental index; $\delta_{\mathrm{ij}}$ : deviation from regression of genotype $\mathrm{i}$ in environment $\mathrm{i}$; and $\varepsilon_{\mathrm{ij}}$ : mean experimental error associated with observation $\mathrm{Y}_{\mathrm{ij}}$.

The estimates of adaptability and stability parameters are the genotype mean $\left(\widehat{\beta}_{0 \mathrm{i}}\right)$ and the linear regression coefficient $\left(\widehat{\beta}_{1 \mathrm{i}}\right)$. According to this methodology, genotypes with $\widehat{\beta}_{1 \mathrm{i}}=1$ have general or wide adaptability; genotypes with $\widehat{\beta}_{1 \mathrm{i}}>1$ have adaptability specific to favorable environments; and those with $\hat{\beta}_{1 \mathrm{i}}>1$ have adaptability specific to unfavorable environments. The $\mathrm{H}_{0}: \widehat{\beta}_{1 \mathrm{i}}=1$ hypothesis was evaluated by the $\mathrm{t}$ test. The stability parameter $\left(\hat{\sigma}_{\mathrm{di}}^{2}\right)$ was estimated by the method of analysis of variance, based on the mean squared deviation from regression of each genotype (MSDi) and the residual mean square (RMS), where, $\hat{\sigma}_{\mathrm{di}}^{2}=(\mathrm{MSDi}$ RMS)/r. Genotypes with non-significant deviations from regression are considered stable, whereas those with significant deviations are considered unstable. The $\mathrm{F}=\mathrm{MSDi} / \mathrm{RMS}$ statistics was applied to test the $\mathrm{H}_{0}: \hat{\sigma}_{\mathrm{di}}^{2}=0$ hypothesis. As an auxiliary measure in the evaluation of genotype stability, the coefficient of determination $\left(\mathrm{R}^{2}\right)$ was employed.

The method proposed by Cruz et al. (1989) is based on the two-segment regression model, where the mean $\left(\widehat{\beta}_{0 \mathrm{i}}\right)$, the linear response to unfavorable environments $\left(\widehat{\beta}_{1 \mathrm{i}}\right)$, and the linear response to favorable environments $\left(\widehat{\beta}_{1 \mathrm{i}}+\right.$ $\widehat{\beta}_{2 \mathrm{i}}$ ) are employed as adaptability parameters. Stability is evaluated based on the deviations from regression $\left(\hat{\sigma}_{\mathrm{di}}^{2}\right)$ of each material, as a function of environmental variations. The following model was adopted:

$$
\mathrm{Y}_{\mathrm{ij}}=\widehat{\beta}_{0 \mathrm{i}}+\widehat{\beta}_{1 \mathrm{i}} \mathrm{I}_{\mathrm{j}}+\widehat{\beta}_{2 \mathrm{i}} \mathrm{T}\left(\mathrm{I}_{\mathrm{j}}\right)+\delta_{\mathrm{ij}}+\mathrm{e}_{\mathrm{ij}}
$$

where, $Y_{i j}$ : average yield of genotype i in environment $j ; \widehat{\beta}_{0 \mathrm{i}}$ : average yield of genotype $i$ across all environments (means of the genotypes were grouped using Scott and Knott's clustering); $\widehat{\beta}_{1 \mathrm{i}}$ : linear regression coefficient that gives the response of genotype $i$ to the variation in the unfavorable environments; $\beta_{2 \mathrm{i}}$ : linear regression coefficient that informs about the response differential of genotype $i$ to the variation in the favorable environments; $\mathrm{I}_{\mathrm{j}}$ : coded environmental index $\left(\sum_{\mathrm{j}}^{\mathrm{i}}=0\right)$, where, $\mathrm{I}_{\mathrm{i}}=\mathrm{Y}_{\mathrm{i}_{\mathrm{i}}}-\mathrm{Y}$..; $\mathrm{T}\left(\mathrm{I}_{\mathrm{i}}\right)=0$ if $\mathrm{I}_{\mathrm{i}}<0$; and $\mathrm{T}\left(\mathrm{I}_{\mathrm{i}}\right)=\mathrm{I}_{\mathrm{i}}-\mathrm{I}_{+}$if $\mathrm{I}_{\mathrm{i}}>$ 0 , in which $I_{+}$: mean of positive $\mathrm{I}_{\mathrm{j}}$ indices; $\delta_{\mathrm{ij}}$ : deviation from regression of genotype $\mathrm{i}$ in environment $\mathrm{j}$; and $\mathrm{e}_{\mathrm{ij}}$ : mean experimental error associated with observation $Y_{\mathrm{ij}}$. Statistical significances relative to the parameters were obtained by the $t$ test through the following hypotheses: $\mathrm{H}_{01}: \widehat{\beta}_{1 \mathrm{i}}=1 ; \mathrm{H}_{02}: \widehat{\beta}_{2 \mathrm{i}}=0$; and $\mathrm{H}_{03}: \widehat{\beta}_{1 \mathrm{i}}+\widehat{\beta}_{2 \mathrm{i}}=1$. As in the method of Eberhart and Russell (1996), the coefficient of determination $\left(\mathrm{R}^{2}\right)$ was used as an auxiliary measure in the evaluation of stability.

All statistical analyses were performed using the computer resources of Genes Software (Cruz, 2013).

\section{Results and Discussion}

Joint analysis of variance revealed a highly significant effect $(P<0.01)$ of genotypes $(G)$, harvests $(H)$, and genotype $\times$ harvest interaction $(\mathrm{G} \times \mathrm{H})$ by the $\mathrm{F}$ test (Table 2$)$. Thus, the significance found for the source of variation genotypes demonstrates the existence of genetic variability across the genotypes involved in this research, which is essential for the continuity of the process of selection of superior genotypes. 
Table 2. Summary of the joint analysis of variance for the dry matter yield trait, in $\mathrm{t} \mathrm{ha}^{-1}$ harvest, evaluated in nine biannual harvests of 73 genotypes of elephant grass for energy generation

\begin{tabular}{lll}
\hline SV & DF & DMY \\
\cline { 2 - 3 } & & Mean square \\
\hline Block & 1 & 263.45 \\
A error & 72 & $183.04^{* *}$ \\
Harvests $(\mathrm{H})$ & 72 & 56.19 \\
B error & 8 & $3868.06^{* *}$ \\
G $\times$ H & 8 & 77.15 \\
C error & 576 & $48.74^{* *}$ \\
\hdashline Overall mean & 576 & 34.67 \\
CV $(\%)$ & 17.56 & \\
\hdashline RMS+/RMS- & 33.53 & \\
\hline
\end{tabular}

Note. $\mathrm{SV}=$ source of variation; $\mathrm{DF}=$ degrees of freedom; $\mathrm{CV}=$ coefficient of variation $(\%) ; * *$ significant at the level of $1 \%$ of probability by $\mathrm{F}$ test.

The significance of the $\mathrm{G} \times \mathrm{H}$ interaction demonstrates that the relative performance of the genotypes was not consistent throughout the successive harvests. Significant $\mathrm{G} \times \mathrm{H}$ interactions in the evaluation of elephant grass for energy generation over several harvests were also reported by Rocha et al. (2015), Araújo et al. (2017), and Silva et al. (2018b).

In this regard, it is of paramount importance to identify genotypes whose productive behavior is superior to that of another, and which have smaller fluctuations in dry matter yield across the harvests performed over the years. Thus, evaluations of phenotypic adaptability and stability should be carried out so that it is possible to identify the genotypes most stable and responsive to environmental variations.

It should be emphasized that the joint analysis of variance was evaluated using Hartley's test (Table 2), given as the ratio between the highest and lowest residual mean square (RMS), which was 6.54. According to Pimentel-Gomes and Garcia (2002), combined analysis of variance can be performed when this ratio is smaller than seven, which was the case in the current experiment. The present result also agrees with Araújo et al. (2017), who evaluated 83 elephant-grass genotypes for energy production at four harvests and obtained a ratio between highest and lowest RMS of 6.57 .

Experimental precision, which can be measured based on the coefficient of variation (CV), was $33.53 \%$. This value is considered acceptable for DMY, which is a quantitative trait whose genetic control involves several genes, making it highly influenced by the environment (Table 2). This CV value is in line with those typically reported in studies with this crop, also in field conditions (Pimentel-Gomes \& Garcia, 2002; Rossi et al., 2014; Rocha et al., 2015; Araújo et al., 2017).

In four (1st, 3rd, 7th, and 8th) of the nine evaluated harvests, the genotypes achieved an average dry matter yield greater than the overall mean. These environments were thus classified as favorable to the development of the evaluated genotypes; i.e., they could take advantage of the environmental conditions and express their genes for that trait, displaying good average performance, as confirmed by the positive environmental indices (Table 3 ). However, the other harvests (2nd, 4th, 5th, 6th, and 9th) had mean dry matter yields smaller than the overall mean and, consequently, a negative environmental index, which caused them to be classified as environments unfavorable to the development of the genotypes. This result was probably due to the smaller precipitation occurring in those periods, which did not benefit the expression of the genes for yield. 
Table 3. Mean dry matter yield ( $\mathrm{t} \mathrm{ha}^{-1}$ harvest), environmental indices, and precipitation per harvest in 73 genotypes of elephant grass for energy generation in Campos dos Goytacazes, RJ, Brazil

\begin{tabular}{llll}
\hline Harvest & Mean $\left(\mathrm{t} \mathrm{ha}^{-1}\right.$ harvest $)$ & Environmental index $\left(\mathrm{I}_{\mathrm{j}}\right)$ & Precipitation** $(\mathrm{mm})$ \\
\hline 1 & 22.89 & 5.33 & 537.2 \\
2 & 10.82 & -6.73 & 223.9 \\
3 & 18.36 & 0.80 & 677.8 \\
4 & 16.85 & -0.70 & 325.3 \\
5 & 16.37 & -1.18 & 313.4 \\
6 & 11.89 & -5.66 & 167.2 \\
7 & 25.57 & 8.01 & 551.6 \\
8 & 22.05 & 4.49 & 512.6 \\
9 & 13.19 & -4.36 & 309.2 \\
- Overall mean & 17.56 & &
\end{tabular}

Note. ** Precipitation corresponds to the sum of the daily amount of rainfall occurring throughout the genotypes' growing period, at each harvest.

Source: Evapotranspiration Station-Irrigation and Agrometeorology Section of PESAGRO-RIO/CEPAAR.

Overall, the large fluctuation in average yield of the genotypes throughout the harvests contributed to the genotype $\times$ harvest interaction. Therefore, investigating the interaction through methodologies of adaptability and stability shall contribute to a more in-depth analysis of the genotypes' performance. Silva et al. (2018b) evaluated elephant grass at annual harvests, and joint analysis of variance showed significant effects of the genotype $\times$ harvest interaction on dry matter yield, indicating that the genotypes showed different production performances at each harvest.

The genotypes were separated into two groups for mean dry matter yield $\left(\widehat{\beta}_{0 \mathrm{i}}\right)$. The overall mean for this trait was $17.56 \mathrm{t} \mathrm{ha}^{-1}$.harvest (Table 4). Of the 73 evaluated genotypes, 39 had a yield greater than the overall mean, characterizing them as those of best adaptability (Vencovsky \& Barriga, 1992).

Most genotypes, however, exhibited wide adaptability, since their regression coefficients did not present significant differences from unity $\left(\widehat{\beta}_{1 \mathrm{i}}=1\right)$, indicating that these genotypes showed wide or general adaptability in the different environmental conditions found across the harvests (Table 4). This result suggests that these genotypes maintain their yield around the overall mean in both favorable and unfavorable environmental conditions.

In terms of performance stability, which is defined by the estimate of deviations from regression $\left(\hat{\sigma}_{\mathrm{di}}^{2}\right)$, among the most adaptable genotypes $\left(\widehat{\beta}_{0 \mathrm{i}}>\right.$ overall mean), only the clones Australiano, Pusa Napier $\mathrm{N}^{\circ} 1$, Mole de Volta Grande, Cubando Pinda, Pusa Napier Gigante, 10 AD IRI, Mercker Santa Rita, Porto Rico 534-B, Elefante C. Itapemirim, and IJ 7139 showed a $\hat{\sigma}_{\mathrm{di}}^{2}$ significantly different from zero, coupled with low coefficients of determination $\left(\mathrm{R}^{2}\right)$. This means that these genotypes showed low performance predictability; i.e., their average yield varied largely throughout the harvests (Table 4).

According to Eberhart and Russell (1996), the ideal genotype is that which has high yields ( $\widehat{\beta}_{0 \mathrm{i}}>$ overall mean), a regression coefficient equal to unity $\left(\widehat{\beta}_{1 \mathrm{i}}=1\right)$ (general adaptability), and zero deviation from regression $\left(\widehat{\sigma}_{\mathrm{di}}^{2}=\right.$ 0 ) (high stability). Therefore, the 24 genotypes fit those three criteria. Among those, the five best-ranking for DYM are Gramafante, Taiwan A-46, Gigante de Pinda, Três Rios, and Guaçu/I.Z.2.

The ideal genotype defined by Cruz et al. (1989) is that which encompasses high yielding ability (high $\hat{\beta}_{0 i}$ ), adaptability to unfavorable environments $\left(\widehat{\beta}_{1 \mathrm{i}}<1\right)$, responsiveness to environmental improvements $\left(\widehat{\beta}_{1 \mathrm{i}}+\widehat{\beta}_{2 \mathrm{i}}>\right.$ $1)$, and high stability (MSdev = zero). However, no such genotype was found in our study (Table 5). Under specific environmental conditions (favorable or unfavorable), however, some genotypes exhibited satisfactory performance in one or another condition (Table 5). 
Table 4. Overall means $\left(\widehat{\beta}_{0 \mathrm{i}}\right)$ and estimates of regression coefficients $\left(\widehat{\beta}_{1 \mathrm{i}}\right)$, deviations from regressions $\left(\hat{\sigma}_{\mathrm{di}}^{2}\right)$, and coefficient of determination $\left(\mathrm{R}^{2}\right)$ according to the method of Eberhart and Russell, for the dry matter yield (t $\mathrm{ha}^{-1}$.harvest) of 73 genotypes of elephant grass under a biannual nine-harvest regime

\begin{tabular}{|c|c|c|c|c|}
\hline Genotype & $\widehat{\beta}_{0 \mathrm{i}}{ }^{(1)}$ & $\widehat{\beta}_{1 \mathrm{i}}{ }^{(2)}$ & $\hat{\sigma}_{\mathrm{di}}^{2(3)}$ & $\mathrm{R}^{2}(\%)$ \\
\hline King Grass & $25.78 \mathrm{a}$ & $1.87 * *$ & $-12.10^{\mathrm{ns}}$ & 95.28 \\
\hline Pasto Panamá & $23.32 \mathrm{a}$ & $1.87 * *$ & $-3.42^{\mathrm{ns}}$ & 88.40 \\
\hline Gramafante & $23.24 \mathrm{a}$ & $1.13^{\mathrm{ns}}$ & $-2.61^{\mathrm{ns}}$ & 72.29 \\
\hline Taiwan A-46 & $23.03 \mathrm{a}$ & $0.62^{\mathrm{ns}}$ & $2.21^{\mathrm{ns}}$ & 37.25 \\
\hline Australiano & $22.61 \mathrm{a}$ & $1.24^{\mathrm{ns}}$ & $33.84 * *$ & 47.62 \\
\hline Gigante de Pinda & $21.54 \mathrm{a}$ & $0.98^{\mathrm{ns}}$ & $-3.40^{\mathrm{ns}}$ & 67.89 \\
\hline Três Rios & $21.52 \mathrm{a}$ & $0.96^{\mathrm{ns}}$ & $-3.40^{\mathrm{ns}}$ & 66.77 \\
\hline Guaçu/I.Z.2 & $21.38 \mathrm{a}$ & $1.09^{\mathrm{ns}}$ & $-9.83^{\mathrm{ns}}$ & 82.94 \\
\hline Pusa Napier $N^{\circ} 1$ & $21.14 \mathrm{a}$ & $1.88 * *$ & $22.26^{*}$ & 72.92 \\
\hline Taiwan A-121 & $21.10 \mathrm{a}$ & $1.54^{\mathrm{ns}}$ & $5.75^{\text {ns }}$ & 75.57 \\
\hline IJ 7125 cv EMP. 308 & $20.61 \mathrm{a}$ & $1.12^{\mathrm{ns}}$ & $-6.38^{\mathrm{ns}}$ & 77.51 \\
\hline Vruckwona africano & $20.60 \mathrm{a}$ & $0.93^{\mathrm{ns}}$ & $4.99^{\mathrm{ns}}$ & 54.10 \\
\hline Duro de Volta Grande & $20.49 \mathrm{a}$ & $1.20^{\mathrm{ns}}$ & $-11.79^{\mathrm{ns}}$ & 88.68 \\
\hline Mole de Volta Grande & $20.32 \mathrm{a}$ & $0.71^{\mathrm{ns}}$ & $33.76^{* *}$ & 22.80 \\
\hline $03 \mathrm{AD}$ IRI & $20.30 \mathrm{a}$ & $1.14^{\mathrm{ns}}$ & $4.37^{\mathrm{ns}}$ & 64.48 \\
\hline Napierzinho & $20.27 \mathrm{a}$ & $1.36^{\mathrm{ns}}$ & $-8.08^{\mathrm{ns}}$ & 85.73 \\
\hline Taiwan A-148 & $20.24 \mathrm{a}$ & $0.76^{\mathrm{ns}}$ & $16.9^{\mathrm{ns}}$ & 34.03 \\
\hline P 241 Piracicaba & $19.63 \mathrm{a}$ & $0.96^{\mathrm{ns}}$ & $0.69^{\mathrm{ns}}$ & 60.68 \\
\hline Albano & $19.40 \mathrm{a}$ & $1.68 *$ & $7.77^{\mathrm{ns}}$ & 77.22 \\
\hline Cubano Pinda & $19.32 \mathrm{a}$ & $0.88^{\text {ns }}$ & $27.05^{*}$ & 34.36 \\
\hline Cuba-115 & $19.26 \mathrm{a}$ & $1.56^{*}$ & $4.09^{\mathrm{ns}}$ & 77.42 \\
\hline Elefante da Colômbia & $19.10 \mathrm{a}$ & $0.73^{\text {ns }}$ & $17.52^{\mathrm{ns}}$ & 31.89 \\
\hline Pusa Gigante Napier & $19.10 \mathrm{a}$ & $1.14^{\mathrm{ns}}$ & $31.06^{* *}$ & 44.68 \\
\hline $10 \mathrm{AD}$ IRI & $19.09 \mathrm{a}$ & $1.95 * *$ & $40.89 * *$ & 66.49 \\
\hline Guaçu & $19.08 \mathrm{a}$ & $1.04^{\mathrm{ns}}$ & $27.74^{\mathrm{ns}}$ & 42.02 \\
\hline Taiwan A-25 & $19.06 \mathrm{a}$ & $1.58 *$ & $-4.07^{\mathrm{ns}}$ & 85.08 \\
\hline Mercker Santa Rita & $18.96 \mathrm{a}$ & $1.04^{\mathrm{ns}}$ & $58.02 * *$ & 30.21 \\
\hline Mineiro & $18.96 \mathrm{a}$ & $0.59^{\mathrm{ns}}$ & $-9.07^{\mathrm{ns}}$ & 55.88 \\
\hline Porto Rico 534-B & $18.92 \mathrm{a}$ & $0.53^{\mathrm{ns}}$ & $26.09 *$ & 16.26 \\
\hline Elefante C. Itapemirim & $18.86 \mathrm{a}$ & $1.10^{\mathrm{ns}}$ & $25.13 *$ & 46.49 \\
\hline Mineirão IPEACO & $18.75 \mathrm{a}$ & $0.90^{\mathrm{ns}}$ & $-13.18^{\mathrm{ns}}$ & 85.44 \\
\hline Vrukwona & $18.68 \mathrm{a}$ & $1.25^{\mathrm{ns}}$ & $5.39^{\mathrm{ns}}$ & 67.54 \\
\hline IJ 7139 & $18.61 \mathrm{a}$ & $1.83 * *$ & $39.42 * *$ & 64.19 \\
\hline Ibitinema & $18.41 \mathrm{a}$ & $0.91^{\mathrm{ns}}$ & $-4.50^{\mathrm{ns}}$ & 65.99 \\
\hline CAC 262 & $18.31 \mathrm{a}$ & $1.23^{\mathrm{ns}}$ & $-5.98^{\mathrm{ns}}$ & 80.13 \\
\hline Cuba-116 & $18.16 \mathrm{a}$ & $1.06^{\mathrm{ns}}$ & $11.26^{\mathrm{ns}}$ & 54.39 \\
\hline Mercker Pinda México & $18.05 \mathrm{a}$ & $0.87^{\mathrm{ns}}$ & $-2.63^{\mathrm{ns}}$ & 61.12 \\
\hline Mercker Pinda & $17.95 \mathrm{a}$ & $1.45^{\mathrm{ns}}$ & $7.40^{\mathrm{ns}}$ & 72.75 \\
\hline BAGCE 69 & $17.70 \mathrm{a}$ & $1.29^{\mathrm{ns}}$ & $8.23^{\mathrm{ns}}$ & 66.45 \\
\hline 05 AD IRI & $17.50 \mathrm{~b}$ & $0.54^{\mathrm{ns}}$ & $7.19^{\text {ns }}$ & 26.53 \\
\hline Cameroon & $17.36 \mathrm{~b}$ & $0.99^{\mathrm{ns}}$ & $12.79^{\mathrm{ns}}$ & 49.52 \\
\hline $07 \mathrm{AD}$ IRI & $17.23 \mathrm{~b}$ & $1.17^{\mathrm{ns}}$ & $-3.34^{\mathrm{ns}}$ & 74.81 \\
\hline 02 AD IRI & $16.74 \mathrm{~b}$ & $1.12^{\mathrm{ns}}$ & $-2.28^{\mathrm{ns}}$ & 71.67 \\
\hline BAGCE2 & $16.74 \mathrm{~b}$ & $1.23^{\mathrm{ns}}$ & $-7.09^{\mathrm{ns}}$ & 81.77 \\
\hline IJ7136 cv EMP. 307 & $16.46 \mathrm{~b}$ & $0.75^{\mathrm{ns}}$ & $-3.28^{\mathrm{ns}}$ & 54.82 \\
\hline $13 \mathrm{AD}$ & $16.20 \mathrm{~b}$ & $0.80^{\mathrm{ns}}$ & $-1.10^{\mathrm{ns}}$ & 54.28 \\
\hline Napier Volta Grande & $16.10 \mathrm{~b}$ & $1.30^{\mathrm{ns}}$ & $107.07 * *$ & 29.28 \\
\hline BAGCE 92 & $15.99 \mathrm{~b}$ & $0.82^{\text {ns }}$ & $-9.72^{\mathrm{ns}}$ & 72.87 \\
\hline Mercker S. E. A & $15.80 \mathrm{~b}$ & $1.01^{\mathrm{ns}}$ & $1.41^{\mathrm{ns}}$ & 62.34 \\
\hline Mercker Comum & $15.79 b$ & $0.56^{\mathrm{ns}}$ & $-13.87^{\mathrm{ns}}$ & 73.30 \\
\hline Mercker 86 México & $15.76 \mathrm{~b}$ & $1.24^{\mathrm{ns}}$ & $11.86^{\mathrm{ns}}$ & 61.49 \\
\hline Costa Rica & $15.71 \mathrm{~b}$ & $0.80^{\mathrm{ns}}$ & $-1.38^{\mathrm{ns}}$ & 54.79 \\
\hline
\end{tabular}




\begin{tabular}{|c|c|c|c|c|}
\hline Teresopólis & $15.57 \mathrm{~b}$ & $0.63^{\mathrm{ns}}$ & $-13.62^{\mathrm{ns}}$ & 76.38 \\
\hline Taiwan A-143 & $15.50 \mathrm{~b}$ & $1.13^{\mathrm{ns}}$ & $-7.11^{\mathrm{ns}}$ & 79.17 \\
\hline Turrialba & $15.46 \mathrm{~b}$ & $0.98^{\mathrm{ns}}$ & $1.76^{\mathrm{ns}}$ & 60.52 \\
\hline Napier S.E.A. & $15.29 \mathrm{~b}$ & $0.73^{\text {ns }}$ & $13.89^{\mathrm{ns}}$ & 34.35 \\
\hline Elefante Híbrido 534-A & $15.21 \mathrm{~b}$ & $0.72^{\mathrm{ns}}$ & $1.29^{\mathrm{ns}}$ & 45.60 \\
\hline BAGCE 51 & $14.73 \mathrm{~b}$ & $0.45^{\mathrm{ns}}$ & $-5.81^{\mathrm{ns}}$ & 35.14 \\
\hline BAG 87 & $14.44 \mathrm{~b}$ & $0.43 *$ & $2.14^{\mathrm{ns}}$ & 22.20 \\
\hline Roxo Botucatu & $14.43 \mathrm{~b}$ & $0.66^{\mathrm{ns}}$ & $-9.42^{\mathrm{ns}}$ & 62.59 \\
\hline Goiano & $14.23 \mathrm{~b}$ & $0.54^{\mathrm{ns}}$ & $-8.04^{\mathrm{ns}}$ & 48.65 \\
\hline Taiwan A-146 & $14.17 \mathrm{~b}$ & $0.62^{\mathrm{ns}}$ & $30.36^{* *}$ & 19.65 \\
\hline BAG 86 & $13.98 \mathrm{~b}$ & $0.66^{\mathrm{ns}}$ & $-2.91^{\mathrm{ns}}$ & 47.65 \\
\hline Capim Cana D'África & $13.48 \mathrm{~b}$ & $0.62^{\mathrm{ns}}$ & $-7.01^{\mathrm{ns}}$ & 53.22 \\
\hline Mercker Comum & $13.37 \mathrm{~b}$ & $0.93^{\text {ns }}$ & $-8.63^{\mathrm{ns}}$ & 74.98 \\
\hline Napier Goiano & $13.23 \mathrm{~b}$ & $0.85^{\mathrm{ns}}$ & $7.82^{\text {ns }}$ & 46.71 \\
\hline Pusa Napier $\mathrm{N}^{\circ} 2$ & $12.97 \mathrm{~b}$ & $0.98^{\mathrm{ns}}$ & $-8.95^{\mathrm{ns}}$ & 77.48 \\
\hline Napier & $12.73 \mathrm{~b}$ & $0.55^{\mathrm{ns}}$ & $-3.85^{\mathrm{ns}}$ & 40.44 \\
\hline $08 \mathrm{AD}$ IRI & $12.70 \mathrm{~b}$ & $0.73^{\mathrm{ns}}$ & $-3.94^{\mathrm{ns}}$ & 54.57 \\
\hline Porto Rico & $12.40 \mathrm{~b}$ & $0.55^{\mathrm{ns}}$ & $-2.09^{\mathrm{ns}}$ & 37.51 \\
\hline $13 \mathrm{AD}$ IRI & $11.92 \mathrm{~b}$ & $1.03^{\mathrm{ns}}$ & $2.07^{\mathrm{ns}}$ & 62.40 \\
\hline Elefante de Pinda & $11.02 \mathrm{~b}$ & $0.59^{\mathrm{ns}}$ & $-6.13^{\mathrm{ns}}$ & 48.86 \\
\hline Roxo & $10.76 \mathrm{~b}$ & $0.27^{*}$ & $-10.43^{\mathrm{ns}}$ & 24.42 \\
\hline Overall mean & 17.56 & & & \\
\hline
\end{tabular}

Note. ${ }^{(1)}$ Values within columns followed by the same letter do not differ by Scott-Knott's test at 5\% probability; **, *, ns = significant $(\mathrm{p}<0.01)$, significant $(\mathrm{p}<0.05)$, and not significant, respectively; ${ }^{(2),(3)}$ significance by the $\mathrm{t}$ test and by the $\mathrm{F}$ test, respectively.

Table 5. Adaptability and stability parameters according to the method of Cruz for dry matter yield $\left(\mathrm{t} \cdot \mathrm{ha}^{-1} \cdot\right.$ harvest of 73 elephant-grass genotypes from nine biannual harvests

\begin{tabular}{|c|c|c|c|c|c|c|c|}
\hline Genotype & $\widehat{\beta}_{0 \mathrm{i}}^{(1)}$ & MU & MF & $\widehat{\beta}_{1 i}^{(2)}$ & $\widehat{\beta}_{1 \mathrm{i}}+\widehat{\beta}_{2 \mathrm{i}}^{(3)}$ & MSdev. & $\mathrm{R}^{2}(\%)$ \\
\hline King Grass & $25.78 \mathrm{a}$ & 18.28 & 35.16 & $1.98 * *$ & $1.11^{\mathrm{ns}}$ & $6.34^{\mathrm{ns}}$ & 97.55 \\
\hline Pasto Panamá & $23.32 \mathrm{a}$ & 16.64 & 31.67 & $1.75^{*}$ & $2.69 *$ & $25.75^{\mathrm{ns}}$ & 90.80 \\
\hline Gramafante & $23.24 \mathrm{a}$ & 18.90 & 28.66 & $1.11^{\mathrm{ns}}$ & $1.23^{\mathrm{ns}}$ & $34.23^{\mathrm{ns}}$ & 72.38 \\
\hline Taiwan A-46 & $23.03 \mathrm{a}$ & 21.59 & 24.84 & $0.61^{\mathrm{ns}}$ & $0.71^{\mathrm{ns}}$ & $45.52^{\mathrm{ns}}$ & 37.36 \\
\hline Australiano & $22.61 \mathrm{a}$ & 18.86 & 27.31 & $1.31^{\mathrm{ns}}$ & $0.77^{\mathrm{ns}}$ & $117.16^{* *}$ & 48.61 \\
\hline Gigante de Pinda & $21.54 \mathrm{a}$ & 17.04 & 27.15 & $1.14^{\mathrm{ns}}$ & $-0.11^{\mathrm{ns}}$ & $20.33^{\mathrm{ns}}$ & 79.92 \\
\hline Três Rios & $21.52 \mathrm{a}$ & 18.18 & 25.71 & $1.01^{\mathrm{ns}}$ & $0.61^{\mathrm{ns}}$ & $31.28^{\mathrm{ns}}$ & 68.04 \\
\hline Guaçu/I,Z,2 & $21.38 \mathrm{a}$ & 17.77 & 25.90 & $1.11^{\mathrm{ns}}$ & $1.03^{\mathrm{ns}}$ & $17.47^{\mathrm{ns}}$ & 82.98 \\
\hline Pusa Napier $N^{\circ} 1$ & $21.14 \mathrm{a}$ & 14.29 & 29.70 & $2.01 * *$ & $0.97^{\mathrm{ns}}$ & $84.02 *$ & 75.38 \\
\hline Taiwan A-121 & $21.10 \mathrm{a}$ & 16.09 & 27.36 & $1.38^{\mathrm{ns}}$ & $2.59 *$ & $42.53^{\mathrm{ns}}$ & 80.71 \\
\hline IJ 7125 cv EMP. 308 & $20.61 \mathrm{a}$ & 16.28 & 26.03 & $1.14^{\mathrm{ns}}$ & $0.93^{\mathrm{ns}}$ & $25.21^{\mathrm{ns}}$ & 77.83 \\
\hline Vruckwona africano & $20.60 \mathrm{a}$ & 17.89 & 24.00 & $0.75^{\mathrm{ns}}$ & $2.19^{\mathrm{ns}}$ & $36.12^{\mathrm{ns}}$ & 68.18 \\
\hline Duro de Volta Grande & $20.49 \mathrm{a}$ & 16.30 & 25.73 & $1.20^{\mathrm{ns}}$ & $1.16^{\mathrm{ns}}$ & $12.93^{\mathrm{ns}}$ & 88.69 \\
\hline Mole de Volta Grande & $20.32 \mathrm{a}$ & 17.20 & 24.21 & $0.82^{\mathrm{ns}}$ & $-0.09^{\mathrm{ns}}$ & $112.84 * *$ & 26.95 \\
\hline 03 AD IRI & $20.30 \mathrm{a}$ & 17.42 & 23.89 & $1.08^{\mathrm{ns}}$ & $1.60^{\mathrm{ns}}$ & $48.54^{\mathrm{ns}}$ & 65.96 \\
\hline Napierzinho & $20.27 \mathrm{a}$ & 15.16 & 26.65 & $1.34^{\mathrm{ns}}$ & $1.45^{\mathrm{ns}}$ & $21.52^{\mathrm{ns}}$ & 85.79 \\
\hline Taiwan A-148 & $20.24 \mathrm{a}$ & 17.03 & 24.25 & $0.77^{\mathrm{ns}}$ & $0.71^{\mathrm{ns}}$ & $79.85^{*}$ & 34.05 \\
\hline P 241 Piracicaba & $19.63 \mathrm{a}$ & 15.28 & 25.08 & $1.10^{\mathrm{ns}}$ & $-0.02^{\mathrm{ns}}$ & $32.33^{\mathrm{ns}}$ & 69.78 \\
\hline Albano & $19.40 \mathrm{a}$ & 12.21 & 28.39 & $1.65^{*}$ & $1.87^{\mathrm{ns}}$ & $58.19^{\mathrm{ns}}$ & 77.37 \\
\hline Cubano Pinda & $19.32 \mathrm{a}$ & 15.56 & 24.02 & $0.79^{\mathrm{ns}}$ & $1.49^{\mathrm{ns}}$ & $99.79 * *$ & 36.76 \\
\hline Cuba-115 & $19.26 \mathrm{a}$ & 13.74 & 26.15 & $1.48^{\mathrm{ns}}$ & $2.12^{\mathrm{ns}}$ & $46.83^{\mathrm{ns}}$ & 78.86 \\
\hline Elefante da Colômbia & $19.10 \mathrm{a}$ & 16.60 & 22.23 & $0.76^{\mathrm{ns}}$ & $0.55^{\mathrm{ns}}$ & $81.00 *$ & 32.18 \\
\hline Pusa Gigante Napier & $19.10 \mathrm{a}$ & 13.85 & 25.67 & $1.35^{\mathrm{ns}}$ & $-0.36^{\mathrm{ns}}$ & $90.11^{*}$ & 55.86 \\
\hline $10 \mathrm{AD}$ IRI & $19.09 \mathrm{a}$ & 12.80 & 26.96 & $1.59 *$ & $4.47 * *$ & $71.48^{\mathrm{ns}}$ & 82.37 \\
\hline Guaçu & $19.08 \mathrm{a}$ & 15.70 & 23.31 & $0.91^{\mathrm{ns}}$ & $1.94^{\mathrm{ns}}$ & $96.99 *$ & 46.53 \\
\hline Taiwan A-25 & $19.06 \mathrm{a}$ & 13.81 & 25.62 & $1.45^{\mathrm{ns}}$ & $2.47^{\mathrm{ns}}$ & $22.88^{\mathrm{ns}}$ & 88.97 \\
\hline
\end{tabular}




\begin{tabular}{|c|c|c|c|c|c|c|c|}
\hline Mercker Santa Rita & $18.96 \mathrm{a}$ & 17.10 & 21.29 & $1.04^{\mathrm{ns}}$ & $1.00^{\mathrm{ns}}$ & $175.82 * *$ & 30.21 \\
\hline Mineiro & $18.96 \mathrm{a}$ & 16.88 & 21.57 & $0.63^{\mathrm{ns}}$ & $0.30^{\mathrm{ns}}$ & $18.46^{\mathrm{ns}}$ & 57.78 \\
\hline Porto Rico 534-B & $18.92 \mathrm{a}$ & 17.18 & 21.10 & $0.55^{\mathrm{ns}}$ & $0.34^{\mathrm{ns}}$ & $100.98^{* *}$ & 16.54 \\
\hline Elefante C. Itapemirim & $18.86 \mathrm{a}$ & 15.35 & 23.24 & $0.91^{\mathrm{ns}}$ & $2.43^{\mathrm{ns}}$ & $81.18^{*}$ & 56.17 \\
\hline Mineirão IPEACO & $18.75 \mathrm{a}$ & 15.97 & 22.24 & $0.84^{\mathrm{ns}}$ & $1.31^{\mathrm{ns}}$ & $7.94^{\mathrm{ns}}$ & 88.07 \\
\hline Vrukwona & $18.68 \mathrm{a}$ & 14.60 & 23.79 & $1.14^{\mathrm{ns}}$ & $2.00^{\mathrm{ns}}$ & $47.32^{\mathrm{ns}}$ & 71.04 \\
\hline IJ 7139 & $18.61 \mathrm{a}$ & 12.10 & 26.75 & $1.50^{\mathrm{ns}}$ & $4.16^{* *}$ & $77.69 *$ & 79.00 \\
\hline Ibitinema & $18.41 \mathrm{a}$ & 15.44 & 22.13 & $0.91^{\mathrm{ns}}$ & $0.86^{\mathrm{ns}}$ & $29.92^{\mathrm{ns}}$ & 66.01 \\
\hline CAC 262 & $18.31 \mathrm{a}$ & 13.11 & 24.81 & $1.26^{\mathrm{ns}}$ & $1.00^{\mathrm{ns}}$ & $25.94^{\mathrm{ns}}$ & 80.54 \\
\hline Cuba-116 & $18.16 \mathrm{a}$ & 14.12 & 23.21 & $1.11^{\mathrm{ns}}$ & $0.74^{\mathrm{ns}}$ & $65.67^{\mathrm{ns}}$ & 55.11 \\
\hline Mercker Pinda México & $18.05 \mathrm{a}$ & 14.66 & 22.29 & $0.96^{\mathrm{ns}}$ & $0.27^{\mathrm{ns}}$ & $30.66^{\mathrm{ns}}$ & 65.27 \\
\hline Mercker Pinda & $17.95 \mathrm{a}$ & 13.01 & 24.11 & $1.36^{\mathrm{ns}}$ & $2.31^{\mathrm{ns}}$ & $50.71^{\mathrm{ns}}$ & 76.07 \\
\hline BAGCE 69 & $17.70 \mathrm{a}$ & 12.34 & 24.40 & $1.28^{\mathrm{ns}}$ & $1.36^{\mathrm{ns}}$ & $59.62^{\mathrm{ns}}$ & 66.47 \\
\hline $05 \mathrm{AD}$ IRI & $17.50 \mathrm{~b}$ & 16.10 & 19.24 & $0.67^{\mathrm{ns}}$ & $-0.37^{\mathrm{ns}}$ & $48.74^{\mathrm{ns}}$ & 37.42 \\
\hline Cameroon & $17.36 \mathrm{~b}$ & 13.15 & 22.63 & $1.07^{\mathrm{ns}}$ & $0.41^{\mathrm{ns}}$ & $66.96^{\mathrm{ns}}$ & 51.92 \\
\hline $07 \mathrm{AD}$ IRI & $17.23 \mathrm{~b}$ & 12.76 & 22.82 & $1.28^{\mathrm{ns}}$ & $0.44^{\mathrm{ns}}$ & $27.21^{\mathrm{ns}}$ & 79.02 \\
\hline $02 \mathrm{AD}$ IRI & $16.74 \mathrm{~b}$ & 11.27 & 23.59 & $1.21^{\mathrm{ns}}$ & $0.48^{\mathrm{ns}}$ & $30.90^{\mathrm{ns}}$ & 75.08 \\
\hline BAGCE2 & $16.74 \mathrm{~b}$ & 11.86 & 22.84 & $1.16^{\mathrm{ns}}$ & $1.70^{\mathrm{ns}}$ & $21.66^{\mathrm{ns}}$ & 83.50 \\
\hline IJ7136 cv EMP. 307 & $16.46 \mathrm{~b}$ & 13.88 & 19.68 & $0.74^{\mathrm{ns}}$ & $0.85^{\mathrm{ns}}$ & $32.70^{\mathrm{ns}}$ & 54.96 \\
\hline $13 \mathrm{AD}$ & $16.20 \mathrm{~b}$ & 13.55 & 19.51 & $0.61^{\mathrm{ns}}$ & $2.11^{\mathrm{ns}}$ & $20.31^{\mathrm{ns}}$ & 75.50 \\
\hline Napier Volta Grande & $16.10 \mathrm{~b}$ & 10.61 & 22.97 & $1.30^{\mathrm{ns}}$ & $1.36^{\mathrm{ns}}$ & $290.26^{* *}$ & 29.29 \\
\hline BAGCE 92 & $15.99 \mathrm{~b}$ & 13.57 & 19.01 & $0.74^{\mathrm{ns}}$ & $1.36^{\mathrm{ns}}$ & $14.82^{\mathrm{ns}}$ & 77.37 \\
\hline Mercker S. E. A & $15.80 \mathrm{~b}$ & 13.00 & 19.30 & $0.93^{\mathrm{ns}}$ & $1.57^{\mathrm{ns}}$ & $40.61^{\mathrm{ns}}$ & 65.05 \\
\hline Mercker Comum & $15.79 \mathrm{~b}$ & 13.33 & 18.86 & $0.60^{\mathrm{ns}}$ & $0.28^{\mathrm{ns}}$ & $7.27^{\mathrm{ns}}$ & 76.01 \\
\hline Mercker 86 México & $15.76 \mathrm{~b}$ & 9.77 & 23.26 & $1.46^{\mathrm{ns}}$ & $-0.30^{\mathrm{ns}}$ & $44.02^{\mathrm{ns}}$ & 75.12 \\
\hline Costa Rica & $15.71 \mathrm{~b}$ & 12.51 & 19.71 & $0.80^{\mathrm{ns}}$ & $0.80^{\mathrm{ns}}$ & $37.24^{\mathrm{ns}}$ & 54.79 \\
\hline Teresopólis & $15.57 \mathrm{~b}$ & 13.42 & 18.25 & $0.61^{\mathrm{ns}}$ & $0.74^{\mathrm{ns}}$ & $8.55^{\mathrm{ns}}$ & 76.69 \\
\hline Taiwan A-143 & $15.50 \mathrm{~b}$ & 11.23 & 20.84 & $1.21^{\mathrm{ns}}$ & $0.59^{\mathrm{ns}}$ & $20.86^{\mathrm{ns}}$ & 81.79 \\
\hline Turrialba & $15.46 \mathrm{~b}$ & 11.17 & 20.83 & $1.08^{\mathrm{ns}}$ & $0.28^{\mathrm{ns}}$ & $39.54^{\mathrm{ns}}$ & 64.96 \\
\hline Napier S.E.A. & $15.29 \mathrm{~b}$ & 12.46 & 18.84 & $0.65^{\mathrm{ns}}$ & $1.33^{\mathrm{ns}}$ & $69.29^{\mathrm{ns}}$ & 37.57 \\
\hline Elefante Híbrido 534-A & $15.21 \mathrm{~b}$ & 11.92 & 19.33 & $0.78^{\mathrm{ns}}$ & $0.26^{\mathrm{ns}}$ & $41.36^{\mathrm{ns}}$ & 48.26 \\
\hline BAGCE 51 & $14.73 \mathrm{~b}$ & 13.13 & 16.73 & $0.53^{\mathrm{ns}}$ & $-0.08^{\mathrm{ns}}$ & $24.06^{\mathrm{ns}}$ & 42.00 \\
\hline BAG 87 & $14.44 \mathrm{~b}$ & 11.94 & 17.57 & $0.59^{\mathrm{ns}}$ & $-0.73 *$ & $31.93^{\mathrm{ns}}$ & 45.33 \\
\hline Roxo Botucatu & $14.43 \mathrm{~b}$ & 12.52 & 16.82 & $0.59^{\mathrm{ns}}$ & $1.14^{\mathrm{ns}}$ & $16.14^{\mathrm{ns}}$ & 67.30 \\
\hline Goiano & $14.23 \mathrm{~b}$ & 12.10 & 16.89 & $0.50^{\mathrm{ns}}$ & $0.79^{\mathrm{ns}}$ & $21.07^{\mathrm{ns}}$ & 50.12 \\
\hline Taiwan A-146 & $14.17 \mathrm{~b}$ & 10.70 & 18.51 & $0.63^{\mathrm{ns}}$ & $0.53^{\mathrm{ns}}$ & $111.20 * *$ & 19.72 \\
\hline BAG 86 & $13.98 \mathrm{~b}$ & 11.21 & 17.45 & $0.69^{\mathrm{ns}}$ & $0.42^{\mathrm{ns}}$ & $33.08^{\mathrm{ns}}$ & 48.54 \\
\hline Capim Cana D'África & $13.48 \mathrm{~b}$ & 11.34 & 16.16 & $0.65^{\mathrm{ns}}$ & $0.45^{\mathrm{ns}}$ & $23.81^{\mathrm{ns}}$ & 53.79 \\
\hline Mercker Comum & $13.37 \mathrm{~b}$ & 10.37 & 17.12 & $0.86^{\mathrm{ns}}$ & $1.37^{\mathrm{ns}}$ & $18.30^{\mathrm{ns}}$ & 77.46 \\
\hline Napier Goiano & $13.23 \mathrm{~b}$ & 9.60 & 17.76 & $0.83^{\mathrm{ns}}$ & $1.02^{\mathrm{ns}}$ & $58.42^{\mathrm{ns}}$ & 46.97 \\
\hline Pusa Napier $N^{\circ} 2$ & $12.97 \mathrm{~b}$ & 9.84 & 16.88 & $0.96^{\mathrm{ns}}$ & $1.12^{\mathrm{ns}}$ & $19.35^{\mathrm{ns}}$ & 77.73 \\
\hline Napier & $12.73 \mathrm{~b}$ & 10.92 & 15.00 & $0.61^{\mathrm{ns}}$ & $0.11^{\mathrm{ns}}$ & $29.47^{\mathrm{ns}}$ & 44.23 \\
\hline 08 AD IRI & $12.70 \mathrm{~b}$ & 8.79 & 17.60 & $0.86^{\mathrm{ns}}$ & $-0.16^{\mathrm{ns}}$ & $23.19^{\mathrm{ns}}$ & 66.30 \\
\hline Porto Rico & $12.40 \mathrm{~b}$ & 9.86 & 15.57 & $0.60^{\mathrm{ns}}$ & $0.23^{\mathrm{ns}}$ & $34.54^{\mathrm{ns}}$ & 39.33 \\
\hline 13 AD IRI & $11.92 \mathrm{~b}$ & 6.95 & 18.12 & $1.12^{\mathrm{ns}}$ & $0.38^{\mathrm{ns}}$ & $40.98^{\mathrm{ns}}$ & 65.96 \\
\hline Elefante de Pinda & $11.02 \mathrm{~b}$ & 8.13 & 14.62 & $0.65^{\mathrm{ns}}$ & $0.19^{\mathrm{ns}}$ & $24.48^{\mathrm{ns}}$ & 52.13 \\
\hline Roxo & $10.76 \mathrm{~b}$ & 10.30 & 11.34 & $0.29 *$ & $0.18^{\mathrm{ns}}$ & $16.01^{\mathrm{ns}}$ & 24.86 \\
\hline Overall mean & 17.56 & 13.83 & 22.22 & & & & \\
\hline
\end{tabular}

Note. $\mathrm{MU}=$ mean of unfavorable environments; $\mathrm{MF}=$ mean of favorable environments; ${ }^{(1)}$ Values within columns followed by the same letter do not differ by Scott-Knott's test at $5 \%$ probability; ${ }^{(2)} \mathrm{H}_{0}=\widehat{\beta}_{1 \mathrm{i}}=1 ;{ }^{(3)} \mathrm{H}_{0}$ $=\widehat{\beta}_{1 \mathrm{i}}+\widehat{\beta}_{2 \mathrm{i}}=1 ; * *, *, \mathrm{~ns}=$ significant $(\mathrm{p}<0.01)$, significant $(\mathrm{p}<0.05)$, and insignificant, respectively, by the $\mathrm{t}$ test.

Genotypes Pasto Panamá, 10 AD IRI, and IJ 7139 showed regression coefficients $\left(\widehat{\beta}_{1 \mathrm{i}}+\widehat{\beta}_{2 \mathrm{i}}\right)$ of $2.69,4.47$, and 4.16, respectively, by the method of Cruz et al. (1989) (Table 5). These values were statistically greater than 
unity, and their magnitude was greater than the respective regression coefficients of $1.87,1.95$, and 1.83 as estimated by the method of Eberhart and Russell (1996). This finding demonstrates that the method of Cruz et al. (1989) is more refined for the recommendation of genotypes for specific environmental conditions-favorable, unfavorable, or both — when compared with the method of Eberhart and Russell (1996).

The estimates of $\widehat{\beta}_{1 \mathrm{i}}$, which evaluates the performance of genotypes in unfavorable conditions, were significant and greater than one for the clones King Grass, Pasto Panamá, Pusa Napier $\mathrm{N}^{\circ} 1$, Albano, and 10 AD IRI, indicating that they are highly sensitive to unfavorable environmental conditions. This result can be verified by the means of those genotypes, since they are among the most productive in the environments considered favorable, with their yield reduced by approximately $50 \%$ in unfavorable environments (Table 5).

As regards the linear response to the favorable environments $\left(\widehat{\beta}_{1 \mathrm{i}}+\widehat{\beta}_{2 \mathrm{i}}\right)$, genotypes Pasto Panamá, Taiwan A-121, 10 AD IRI, and IJ 7139 showed results significantly greater than one. Further, all have dry matter yields greater than the overall mean $\left(\widehat{\beta}_{0 \mathrm{i}}>\right.$ overall mean). In this way, these genotypes were considered adapted to favorable environments and responsive to environmental improvements.

The analyses of stability and adaptability based on the methods of Eberhart and Russel (1996) and Cruz et al. (1989) present more-simplified applications. They allow for statistical tests to more accurately identify the most stable genotypes and the group of environments to which they are best adapted (Oliveira et al., 2006).

\section{Conclusions}

The method of Eberhart and Russel was effective in the identification of elephant grass genotypes with wide adaptability and high dry matter production stability throughout the nine harvests.

When the method of Cruz was used, no genotypes were found comprising high yielding ability, adaptability to unfavorable environments, responsiveness to environmental improvement, and high stability altogether.

Genotypes Gramafante, Taiwan A-46, Gigante de Pinda, Três Rios, Guaçu/I.Z.2, Taiwan A-121, IJ7125 cv EMP. 308, Vruckwona Africano, Duro de Volta Grande, 03 AD IRI, and Napierzinho stood out for displaying high yielding ability, wide adaptability, and production stability simultaneously. Therefore, these genotypes are potential candidates for use in breeding programs aiming at energy generation.

\section{Acknowledgements}

We thank the Coordination of Improvement of Higher Education Personnel (CAPES), the National Council for Scientific and Technological Development (CNPq) and the Research Support Foundation of the State of Rio de Janeiro (FAPERJ) Carlos Chagas Filho de Amparo for the financial support, Embrapa Dairy Cattle for the availability of plant material, the Universidade Estadual do Norte Fluminense Darcy Ribeiro (UENF) for the support and logistics provided to the research.

\section{References}

American Psychological Association. (1972). Ethical standards of psychologists. Washington, DC: American Psychological Association.

Araújo, M. S. B., Daher, R. F., Menezes, B. R. S., Gravina, G. A., Silva, V. B., Rodrigues, E. V., ... Ponciano, N. J. (2017). Stability of annual biomass energy production of elephant grass (Pennisetum purpureum Schum.) genotypes in the Northern region of the Rio de Janeiro State, Brazil. Genetics and Molecular Research, 16(3), 1-11. https://doi.org/10.4238/gmr16039041

Cruz, C. D. (2013). GENES - A software package for analysis in experimental statistics and quantitative genetics. Acta Scientiarum Agronomy, 35, 271-276. https://doi.org/10.4025/actasciagron.v35i3.21251

Cruz, C. D., Carneiro, P. C. S., \& Regazzi, A. J. (2014). Modelos biométricos aplicados ao melhoramento genético. Viçosa, Editora UFV.

Cruz, C. D., Regazzi, A. J., \& Carneiro, P. C. S. (2012). Modelos biométricos aplicados ao melhoramento genético. Viçosa, Editora UFV.

Cruz, C. D., Torres, R. A. A., \& Vencovsky, R. (1989). An alternative approach to the stability analysis proposed by Silva and Barreto. Revista Brasileira de Genética, 12, 567-580.

Cunha, M. V., Lira, M. D. A., Santos, M. V., Júnior, J. C. D., Mello, A. C., \& Freitas, E. V. (2013). Adaptabilidade e estabilidade da produção de forragem por meio de diferentes metodologias na seleção de clones de Pennisetum spp. Revista Brasileira de Ciências Agrárias, 8(4), 681-686. https://doi.org/10.5039/ agraria.v8i4a3280 
Daher, R. F., Souza, M. D., Gravina, G., Machado, J. C., Ramos, H. C. C., Silva, V. Q. R., ... Gottardo, R. D. (2014). Use of elephant grass for energy production in Campos dos Goytacazes-RJ, Brazil. Genetics and Molecular Research, 13(4), 10898-10908. https://doi.org/10.4238/2014

Eberhart, S. A., \& Russel, W. A. (1996). Stability parameters for comparing. Crop Science, 6, 36-40. https://doi.org/10.2135/cropsci1966.0011183X000600010011x

EMBRAPA. (2006). Sistema brasileiro de classificação de solos (2nd ed.). Rio de Janeiro, Empresa Brasileira de Pesquisa Agropecuária Solos.

Freitas, R. S., Barbé, T. D. C., Daher, R. F., Vidal, A. K. F., Stida, W. F., Silva, V. B., ... Pereira, A. V. (2018). Chemical composition and energy yield of elephant-grass biomass as function of five different production ages. Journal of Agricultural Science, 10(1), 1-11. https://doi.org/10.5539/jas.v10n1p343

Ibrahim, N., Kamarudin, S. K., \& Minggu, L. J. (2014). Biofuel from biomass via photo-electrochemical reactions: An overview. Journal of Power Sources, 259, 33-42. https://doi.org/10.1016/j.jpowsour. 2014.02.017

Köppen, W. (1948). Climatologia: con un estudio de los climas de la tierra. México D.F, Fondo de Cultura Econômica.

Lima, R. S., Daher, R. F., Goncalves, L. S., Rossi, D. A., Amaral Júnior, A. T., Pereira, M. G., \& Lédo, F. J. S. (2011). RAPD and ISSR markers in the evaluation of genetic divergence among accessions of elephant grass. Genetics and Molecular Research, 10(3), 1304-1313. https://doi.org/10.4238/vol10-3gmr1107

Magalhões, M. A., Donato, D. B., Canal, W. D., Carneiro, A. D. C. O., Pereira, B. L. C., \& Vital, B. R. (2017). Caracterização de pellets produzidos a partir de capim-elefante para uso energético. Revista Ciência da Madeira, 7(3), 155-162. https://doi.org/10.15210/cmad.v7i3.6819

Menezes, B. R. S., Daher, R. F., Gravina, G. A., Gottardo, R. D., Schneider, L. S. A., \& Rocha, A. S. (2016). Comportamento Per se de híbridos de capim-elefante para fins energéticos. Comunicata Scientiae, 7(1), 73-85. https://doi.org/10.14295/cs.v7i1.946

Mohammed, I. Y., Abakr, Y. A., Kazi, F. K., Yusup, S., Alshareef, I., \& Chin, S. A. (2015). Comprehensive characterization of Napier grass as a feedstock for thermochemical conversion. Energies, 8(5), 3403-3417. https://doi.org/10.3390/en8053403

Morais, R. F. D., Souza, B. J. D., Leite, J. M., Soares, L. H. D. B., Alves, B. J. R., Boddey, R. M., \& Urquiaga, S. (2009). Elephant grass genotypes for bioenergy production by direct biomass combustion. Pesquisa Agropecuária Brasileira, 44(2), 133-140. https://doi.org/10.1590/S0100-204X2009000200004

Oliveira, M. A. R., Pípolo, V. C., Schuster, I., Vicente, D., Dellagostin, M., \& Oliveira, E. F. (2006). Soybean stability and adaptability in Southern and Central Brazil. Crop Breeding and Applied Biotechnology, 6(1), 55-64. https://doi.org/10.12702/1984-7033.v06n01a08

Oliveira, M. L. F., Daher, R. E. F., Gravina, G. A., Silva, V. B., Rodrigues, E. V. O., Shimoya, A., ... Rocha, A. S. (2014). Pre-breeding of elephant grass for energy purposes and biomass analysis in Campos dos Goytacazes-RJ, Brazil. African Journal of Agricultural Research, 9(36), 2743-2758. https://doi.org/ 10.5897/AJAR2014.8900

Oliveira, M. L., Daher, R. F., Menezes, B. R., Vivas, M., Rocha, A. D. S., Ponciano, N. J., ... Silva, V. B. (2017). Genetic diversity of elephant grass (Cenchrus purpureus [Schumach.] Morrone) for energetic production based on quantitative and multi-category traits. Chilean Journal of Agricultural Research, 77(1), 48-57. https://doi.org/10.4067/S0718-58392017000100006

Paterlini, E. M., Arantes, M. D. C., Gonçalves, F. G., Vidaurre, G. B., Oliveira Bauer, M., \& Moulin, J. C. (2013). Avaliação do capim elefante para uso energético. Journal of Biotechnology and Biodiversity, 4(2), $126-133$. https://doi.org/10.20873/jbb.uft.cemaf.v4n2.paterlini

Pimentel-Gomes, F., \& Garcia, C. H. (2002). Estatística aplicada a experimentos agronômicos e florestais: Exposição com exemplos e orientações para uso de aplicativos (p. 271). Piracicaba: FEALQ, Goiânia.

Ramalho, M. A. P., Ferreira, D. F., \& Oliveira, A. C. (2005). Experimentação em genética e melhoramento de plantas. Lavras, Universidade Federal de Lavras.

Rocha, A. S., Daher, R. E. F., Gravina, G. A., Pereira, A. V., Rodrigues, E. V. O., Viana, A. P., \& Oliveira, E. S. (2015). Comparison of stability methods in elephant-grass genotypes for energy purposes. African Journal of Agricultural Research, 10(47), 4283-4294. https://doi.org/10.5897/AJAR2015.10218 
Rossi, D. A., Menezes, B. R. S., Daher, R. F., Gravina, G. A., Lima, R. N., Ledo, F. J. S., ... Souza, C. L. M. (2014). Canonical correlations in elephant grass for energy purposes. African Journal of Biotechnology, 13(36), 3666-3671. http://doi.org/10.5897/AJB2014.13915

Silva, D. J., \& Queiroz, A. C. (2002). Análise de alimentos: Métodos químicos e biológicos (p. 235). Viçosa, Editora UFV.

Silva, V. B. D., Daher, R. F., Menezes, B. R. S., Gravina, G. D. A., Araújo, M. D. S. B. D., Carvalho Júnior, A. R. D., ... Tardin, F. D. (2018a). Selection among and within full-sib families of elephant grass for energy purposes. Crop Breeding and Applied Biotechnology, 18(1), 89-96. https://doi.org/10.1590/1984-70332018 v18n1a12

Silva, V. B. D., Daher, R. F., Menezes, B. R. S., Oliveira, M. L. F., Araújo, M. S. B., \& Novo, A. A. C. (2018b). Different stability methods for cultivar recommendation in elephant-grass for energy purposes in Brazil. Cerne, 23(4), 507-515. https://doi.org/10.1590/01047760201723042292

Silva, V. B., Daher, R. F., Araújo, M. S. B., Souza, Y. P., Cassaro, S., Menezes, B. R. S., ... Amaral Junior, A. T. (2017). Prediction of genetic gains by selection indices using mixed models in elephant grass for energy purposes. Genetics and Molecular Research, 16, 1-8. https://doi.org/10.4238/gmr16039781

Sobrinho, F. D., Pereira, A. V., Ledo, F. J. D. S., Botrel, M. A., Oliveira, J. S., \& Xavier, D. F. (2005). Avaliação agronômica de híbridos interespecíficos entre capim-elefante e milheto. Pesquisa Agropecuária Brasileira, 40(9), 873-880. http://doi.org/10.1590/S0100-204X2005000900006

Sousa, L. B., Daher, R. F., Menezes, B. R. S., Rodrigues, E. V., Tardin, F. D., Gravina, G. A., \& Pereira, A. V. (2016). Qualidade da biomassa em híbridos de capim-elefante para fins energéticos. Revista Brasileira de Ciências Agrárias, 11(2), 85-91. https://doi.org/10.5039/agraria.v11i2a5370

Souza, Y. P., Daher, R. F., Pereira, A. V., Silva, V. B., Freitas, R. S., \& Gravina, G. A. (2017). Repetibilidade e número mínimo de avaliações para caracteres morfoagronômicos de capim-elefante para fins energéticos. Revista Brasileira de Ciências Agrárias, 12(3), 391-397. https://doi.org/10.5039/agraria.v12i3a5456

Vencovsky, R., \& Barriga, P. (1992). Genética biométrica no fitomelhoramento (p. 496). Ribeirão Preto Sociedade Brasileira de Genética.

\section{Copyrights}

Copyright for this article is retained by the author(s), with first publication rights granted to the journal.

This is an open-access article distributed under the terms and conditions of the Creative Commons Attribution license (http://creativecommons.org/licenses/by/4.0/). 